\title{
Physico-Chemical Characterization of Ilex paraguariensis St. Hil. During the Maturation
}

\author{
Ivanor Zaions ${ }^{1}$, Ana Paula Picolo ${ }^{2}$, Itamar Luís Gonçalves ${ }^{3}$, Ana Claudia Piovezan Borges ${ }^{4}$ \\ and Alice Teresa Valduga ${ }^{4 *}$ \\ ${ }^{1}$ Departamento de Ciências Exatas e da Terra; Universidade Regional Integrada do Alto Uruguai e das Missões. \\ ${ }^{2}$ Departamento de Ciências Agrárias; Universidade Regional Integrada do Alto Uruguai e das Missões. \\ ${ }^{3}$ Departamento de Ciências da Saúde; Universidade Regional Integrada do Alto Uruguai e das Missões. ${ }^{4}$ Programa \\ de Pós-Graduação em Ecologia; Universidade Regional Integrada do Alto Uruguai e das Missões; Erechim - RS - \\ Brasil
}

\begin{abstract}
In Brazil, yerba mate is consumed after processing; however, in Chile and Uruguay, the consumers prefer the cured product, which acquires a yellow color. For that yerba-mate is stored for a period of six months to one year, which increases the cost of the final product for the overseas market. This study evaluated the effect of humidity and temperature in maturation chamber on the time required for the product to get this characteristic. The changes in the color, $\mathrm{pH}$, moisture and water activity were evaluated during the time of storage in different conditions of temperature and humidity. Yerba-mate subjected to higher temperature and humidity showed nearest color of the product submitted to natural storage. The loss of green color was related to the reduction in $\mathrm{pH}$ and increase in the moisture of the samples. The higher humidity allowed the mate to reach conditions near to market requirements abroad in approximately 60 days of maturation.
\end{abstract}

Key words: Yerba-mate, early maturation, color

\section{INTRODUCTION}

Yerba-mate (Ilex paraguariensis St. Hil) is a native species from South America cultivated in south of Brazil, Argentina, Paraguay and Uruguay (Hao et al. 2013). Brazil is responsible for $63.40 \%$ of world production and the biggest productive areas distributed between South and the estates of Mato Grosso do Sul and São Paulo (Gorenstein et al. 2007; Malheiros 2007). In some South America countries, the leaves and branches infusion is consumed like 'chimarrão', featured as a principal cultural habits.

Yerba-mate industrial processing involves different phases that can modify its chemical composition and change the flavor of the final product, consisting basically of three steps: roasting, drying and grinding (Isolabella et al. 2010; Valerga et al. 2012). During the roasting, the leaves and branches are exposed quickly to fire in a furnace to inactivate the enzymes, which cause oxidation of the product. The drying is done in two types of dryers, rotary dryer and belt dryer. In rotary dyer, smoke of the fire makes direct contact with the raw material, while in the belt dryer, there is no such contact, resulting, less damage to the raw material (Schmalko et al. 2005; Vieira et al. 2010).

The consumers priority of yerba-mate in Brazil is with a green color; however, in Chile and Uruguay

*Author for correspondence: valice@uricer.edu.br 
they prefer the product with a yellow color (Valduga et al. 2003), which is due to the degradation of chlorophyll (Nabechima et al. 2014). To acquire this characteristic, milled yerbamate is stored for six months to one year, which provides color and flavor of a matured product (Isolabella et al. 2010). However, the time of storage increases the costs of the product destined to export.

The methods for the measurement of color intensity include simple visual comparison with the standards or measure by colorimeters and spectrophotometers. The instrumental analysis to measure the color eliminate the subjective aspect of visual assessment (Savadkoohi et al. 2014). This work studied the colorimetric evaluation of yerba-mate processed samples on different drying systems with the aim to reduce the time of maturation.

\section{METHODS}

Samples of yerba-mate processed and vacuum packed for the traceability and from to different lots were obtained from Barão Yerba-Mate and Teas - Barão de Cotegipe/RS. The samples were submitted to different processing: (1) belt dryer input $350{ }^{\circ} \mathrm{C}$, output $70^{\circ} \mathrm{C}$; (2) rotary dryer $-8 \mathrm{rpm}$, $90^{\circ} \mathrm{C}$; and (3) processing in a laboratory roaster with the use of liquefied petroleum gas with mass flow of $2.1 \cdot 10^{-4} \mathrm{Kg} \cdot \mathrm{s}^{-1}$. (Valduga et al. 2003), followed by drying in a fixed bed dryer with hot air stream at $70^{\circ} \mathrm{C}$. Samples were exposed to three systems of storage: environmental conditions of temperature and humidity, in maturation chamber at $40^{\circ} \mathrm{C} / 60 \% \mathrm{RH}$ and $40^{\circ} \mathrm{C} / 90 \% \mathrm{RH}$. The colorimetric parameters obtained from the samples had as reference values measured in a yerba-mate sample meant for the export, which were storage for six months.

To evaluate quantitatively the changes produced by the storage, concomitantly with color the chlorophyll content of maturated and nonmaturated yerba-mate samples was measured spectrophotometrically (Moran, 1982). The color was measured valuation by a colorimeter (Minolta CR 400), with CIELab system scales, where L" represented the luminosity varying from 0 (black) to 100 (white) and parameters 'a', and ' $b$ "' colorimetric coordinates $(-\mathrm{a}=$ green, $+\mathrm{a}=\mathrm{red} ;-\mathrm{b}=$ blue $\mathrm{e}+\mathrm{b}=$ yellow), both ranging from -60 to +60 . For moisture determination, $10 \mathrm{~g}$ of material was heated at $105^{\circ} \mathrm{C}$ for $3 \mathrm{~h}$, cooled and weighed until constant mass. The water activity was determined with the apparatus Aqua-lab, model CX-2, at $25^{\circ} \mathrm{C}$. The $\mathrm{pH}$ was measured in a $0.1 \mathrm{~g} \cdot \mathrm{mL}^{-1}$ solution using a digital potentiometer.

All the measurements were done in triplicate and the results were expressed as mean \pm standard deviation. For means comparison $t$ test or variance analysis ANOVA following the Tukey test were used and the level of significance adopted was $5 \%$ $(\mathrm{p}<0.05)$.

\section{RESULTS}

Drying system did not affect the standard of changes observed according to time for the parameters evaluated. For this reason, it was decided to describe just the behavior of these parameters in the samples processed on belt dryer. The colorimetric parameters of yerba-mate submitted to natural storage and non-matured yerba-mate are presented in Table 1, and same comparison to chlorophyll and pheophytins pigments concentration is presented in Figure 1.

Table 1 - Parameters $L^{*}, a^{*}$ e $b^{*}$ of yerba-mate sample submitted to natural storage.

\begin{tabular}{lccc}
\hline Parameter & $\begin{array}{c}\text { Matured } \\
\text { yerba-mate }\end{array}$ & $\begin{array}{c}\text { Non-matured } \\
\text { yerba-mate }\end{array}$ & p value \\
\hline Luminosity $\left(\mathrm{L}^{*}\right)$ & $42.120 \pm 2.207$ & $45.803 \pm 1.573$ & 0.0186 \\
Green color $\left(\mathrm{a}^{*}\right)$ & $-1.908 \pm 0.262$ & $-8.693 \pm 0.214$ & $<0.0001$ \\
Yellow color $\left(\mathrm{b}^{*}\right)$ & $11.147 \pm 0.808$ & $20.097 \pm 0.337$ & $<0.0001$ \\
\hline
\end{tabular}

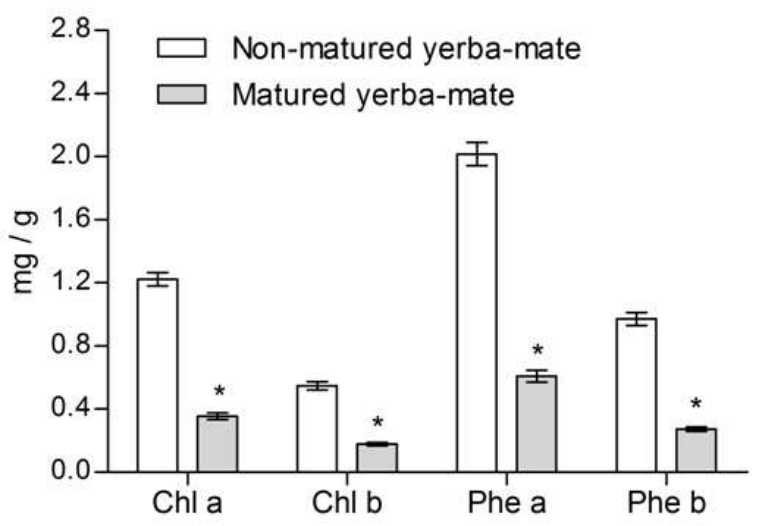

Figure 1 - Concentration of chlorophylls (Chl) and pheophytins (Phe) in non-matured and matured yerba-mate. $(*) \mathrm{p}<0.05$.

The measured values of the colorimetric coordinates for the matured yerba-mate were compared during the storage (Fig. 2). The 
parameter $\mathrm{a}^{*}$ in a chamber at $40^{\circ} \mathrm{C} / 60 \% \mathrm{RH}$ showed no statistically significant differences in relation to yerba-mate naturally stored for 45 and 60 days. The samples in a chamber at $40^{\circ} \mathrm{C} / 90 \%$ RH didn't differ from the control at 30 days (Fig. 2A). The samples subjected to conditions $40^{\circ} \mathrm{C} / 90 \% \mathrm{RH}$ showed no statistically significant differences in relation to the parameters $\mathrm{b}^{*}$ and $\mathrm{L}^{*}$ at 60 days of storage (Fig. 2B and 2C). In all samples there was a reduction in $\mathrm{pH}$ and an
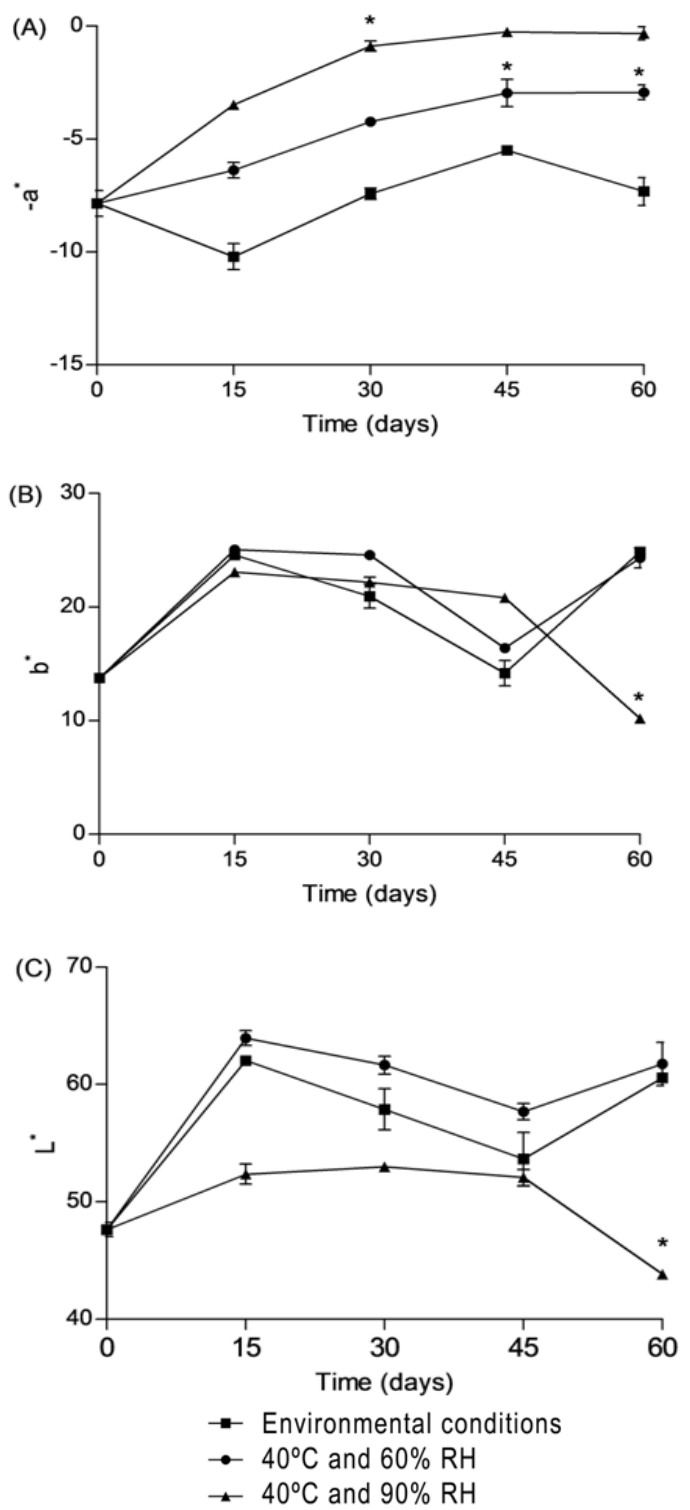

Figure 2 - Color variation according to time in different conditions of storage. The (*) indicates instants of storage that weren't observed differences statistically significant due to natural storage, following Tukey test with reliable $95 \%$. increase in moisture and water activity according to time. These changes were more pronounced under the conditions of high humidity of maturation chamber (Fig. 3). There was a correlation between the loss of green color with the variation of moisture and $\mathrm{pH}$ of the sample (Fig. 4). Such parameters could be important to characterize the product during the maturation process.
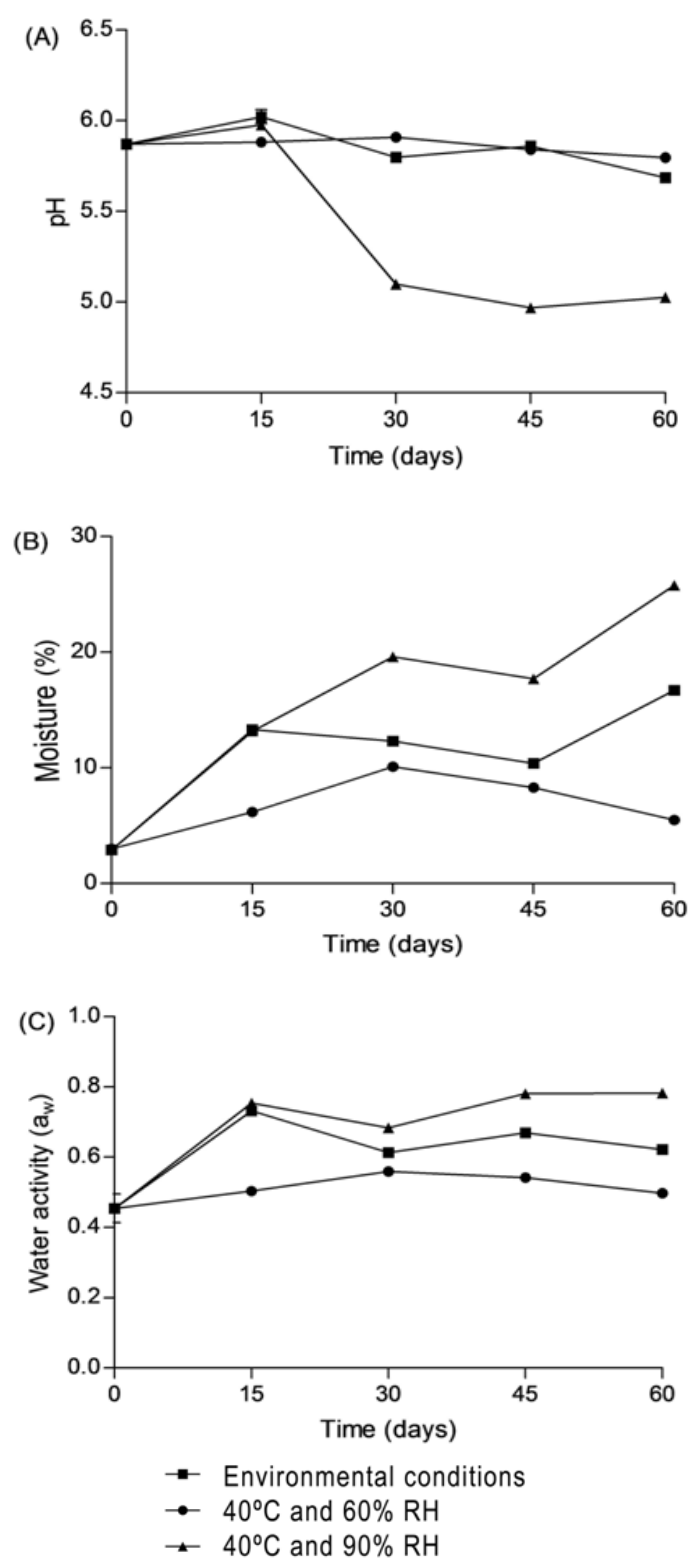

Figure 3 - Variation of $\mathrm{pH}$, moisture and water activity according to time of samples exposure. 

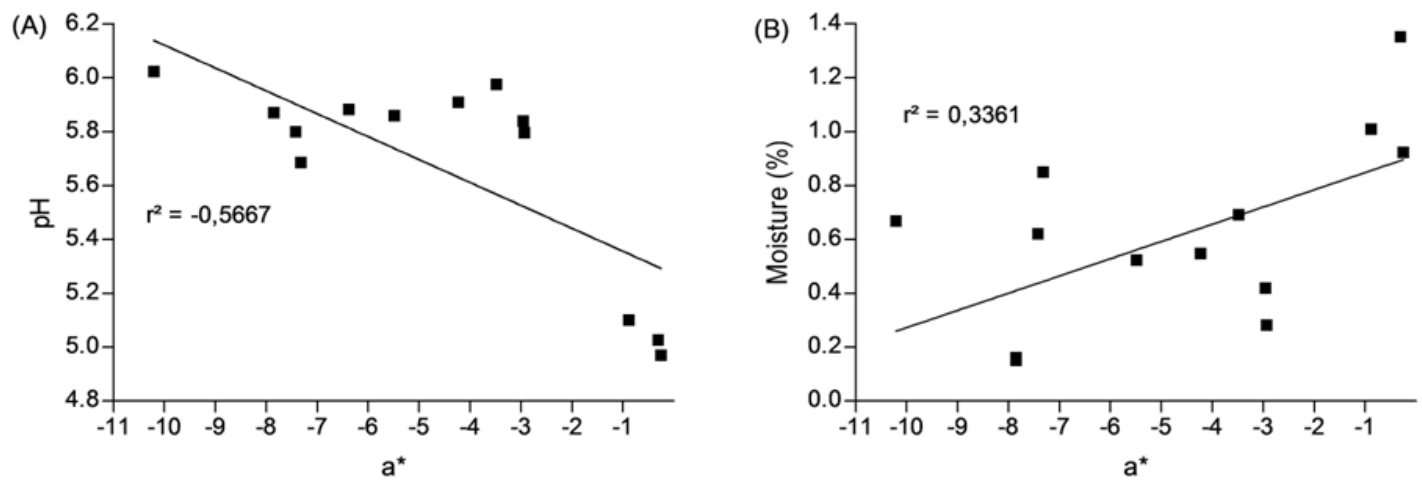

Figure 4 - Relation between parameters physico-chemicals analyzed and green color. In (A) correlation to $\mathrm{pH}(\mathrm{p}=0.0012)$ and in $(\mathrm{B})$ of moisture $(\mathrm{p}=0.0298)$ with green color degradation.

\section{DISCUSSION}

Other studies have demonstrated increased luminosity and yellowness concomitantly with the reduction of green color over the storage (Trela et al. 2011). In the present study, one of the trials was an exception to this behavior. The luminosity and yellow color between 45 and 60 days of storage in high humidity were reduced, possibly due to the high humidity. Studies have indicated that the loss of the yellow color in the shelf life is caused by the oxidation reactions (Malheiros 2007). The decrease in green color is due to chlorophyll degradation, which was more intense when the water activity was high (Schmalko and Alzamora 2005). The degradation of chlorophyll was also associated with a reduction in $\mathrm{pH}$. Previous studies that evaluated the chlorophyll kinetics degradation in the peas demonstrated that its half-life was reduced at low $\mathrm{pH}$ and high temperature, adjusting to a first-order kinetic model (Koca et al. 2006). The decrease in the chlorophylls and pheophytins levels also was observed during the yerba-mate self-life (Malheiros 2007). Changes in the color also occurred during the shelf-life of yerba-mate. During 180 days, the parameters $\mathrm{L} *, \mathrm{a} *$ and $\mathrm{b} *$ were measured each 30 days and varied significantly between the consecutive measurements (Santos 2004).The sensory attributes such as color, taste, aroma and appearance of a food contribute to its acceptability, showing varied standards depending on the consumer market.

\section{CONCLUSION}

High humidity yielded the product with the characteristics close to that required by the market after 60 days maturation, in which the colorimetric coordinate $\mathrm{a}^{*}$ was the nearest of matured product. The green color degradation was associated with increased moisture and $\mathrm{pH}$ reduction.

\section{REFERENCES}

Gorenstein MR, Barbosa RZ, Ribeiro ER, Bueno JL, Fernendes JMO, Pereira LHP. Evolução da cultura de erva-mate no Brasil durante o período de 1995 a 2005. Rev Eletrôn Agron. 2007; 11: 1-7.

Hao D, Gu X, Xiao, P, Liang Z, Xu L, Peng Y. Research progress in the phytochemistry and biology of Ilex pharmaceutical resources. APSB. 2013; 3:819.

Isolabella S, Cogoi L, López P, Anesini C, Ferraro G, Filip R. Study of the bioactive compounds variation during yerba mate (Ilex paraguariensis) processing. Food Chem. 2010; 122: 695-99.

Koca N, Karadeniz F, Burdurlu HS. Effect of pH on chlorophyll degradation and colour loss in blanched green peas. Food Chem. 2006; 100: 609-615.

Malheiros GC. Learning about color change and chlorophyll degradation during storage of "erva-mate chimarrão". [Dissertation]. Santa Maria: UFSM; 2007.

Moran R. Formulae for determination of chlorophyllous pigments extracted with n,n-dimethylformamid. Plant Physiol. 1982; 69: 1376-81. 
Nabechima GH, Provesi JG, Henriquez Mantelli MB, Vieira MA, De Mello Castanho Amboni RD, Amante ER. Effect of the mild temperature and traditional treatments on residual peroxidase activity, color, and chlorophyll content on storage of mate (Ilex paraguariensis) tea. J Food Sci. 2014; 79:163-168.

Santos KA. Stability of the mate (Ilex paraguariensis St. Hil.) in plastic packings [Dissertation]. Curitiba: Universidade Federal do Paraná; 2004.

Savadkoohi S, Hoogenkamp H, Shamsi K, Farahnaky A. Color, sensory and textural attributes of beef frankfurter, beef ham and meat-free sausage containing tomato pomace. Meat Sci. 2014; 97:410418.

Schmalko ME, Alzamora SM. Modelling the drying of a twig of "yerba mate" considering as a composite material Part II: mathematichal model. J Food Engr. 2005; 67:267-72.

Schmalko ME, Scipioni PG, Ferreyra DJ. Effect of water activity and temperature in color and chlorophylls changes in yerbe-mate leaves. Int J Food Prop. 2005; 8: 313-322.
Trela VD, Byczco M, Schmalko E. Estudio de las variaciones de las propriedades de la yerba-mate durante el estacionemiento. In: $5^{\circ}$ Congreso Sudamericano de la Yerba Mate; 2011; Posadas, Argentina: Instituto Nacional de la yerba-mate, 2011; p. 303-308.

Valduga AT, Finzer JRD, Mosele SH. Processamento de erva-mate. Erechim: EdiFAPES; 2003.

Valerga J, Reta M, Lanari MC, Polyphenol input to the antioxidant activity of yerba mate (Ilex paraguariensis) extracts. LWT-Food Sci Technol. 2012; 45(1): 28-35.

Vieira MA, Maraschin M, Rovaris AA, Amboni RD, Pagliosa CM, Xavier JJ, et al. Occurrence of polycyclic aromatic hydrocarbons throughout the processing stages of erva-mate (Ilex paraguariensis). Food Addit Contam Part A. 2010; 27:776-782.

Received: June 06, 2013; Accepted: January 30, 2014. 